\title{
A Political Fugitive: The Case of Little Rock Reed (A Story of Due Process the American Way)
}

Deborah Garlin'

Many of the readers of the Journal of Prisoners on Prisons (JPP) are familiar with Little Rock Reed's advocacy for the rights of American Indians and prisoners, since he has published various articles in the Journal (Reed 1989; 1990; 1993a; 1993b; Morgan and Reed 1993). Most of you are probably not aware, however, that since the last issue of the $J P P$, which he co-edited, Little Rock has been forced underground and has become a political fugitive. As a personal friend and as an attorney working with him on behalf of the Aboriginal Uintah Nation, I am impelled to write about his personal circumstances that continue to impede the progress of our work.

On July 5, 1993, several well known and highly regarded social scientists and attorneys ${ }^{2}$ submitted a petition for clemency/pardon to George Voinovich, governor of Ohio, on Little Rock's behalf. Their petition stated:

After having carefully reviewed the enclosed 'Statement of Facts Regarding Little Rock (aka Timothy) Reed's Situation With the Ohio Adult Parole Authority' and supporting documentation attached thereto, it is our informed opinion that Little Rock Reed, an articulate human rights advocate for American Indians and prisoners, has been made to serve many years in Ohio's maximum security prison solely and expressly because of his legitimate and peaceful activism.

In our opinion, the enclosed evidence indicates that because Little Rock Reed, while on parole, was exposing civil and criminal violations which have been and continue to be committed by the Ohio Adult Parole Authority (APA), the Ohio Department of Rehabilitation and Correction, and other agencies that have influence with the APA, the APA intends to use its power to place Little Rock back in prison for up to fifteen more years in order to silence his voice. In fact, the evidence is so overwhelming that on June 4, 1993, after reviewing only a very small portion of [Little Rock's sworn affidavit and supporting documents], a Kenton County, Kentucky judge [acknowledged] that Little Rock's life is [indeed] in danger due to the fact that the APA has plans to politically imprison - and very possibly to politically assassinate - Little Rock if and when he comes out of hiding ....

The petitioners also told Governor Voinovich that, even though under Ohio law, petitions for clemency or pardon are to be submitted to the APA for their review and recommendation, 'in light of the APA's apparent conflict of interest in this particular case, such procedure 
would be entirely inappropriate' and 'would preclude Little Rock from being given real consideration for pardon or clemency.'

Notwithstanding the above, on July 28, 1993, Governor Voinovich forwarded the petition to the APA for their recommendation. On July 30, 1993, the Ohio Parole Board denied the petition, stating that Little Rock's petition will be given no consideration until he is back in the APA's custody.

For those of us familiar with the facts set out in the petition, the Ohio Parole Board's response is appalling. Little Rock's affidavit, which is reproduced below, speaks for itself: ${ }^{3}$

1 I was convicted for aggravated robbery and sentenced to 7 to 25 years in the Ohio Department of Rehabilitation and Correction (ODRC). My sentence began in May of 1982.

2 Under Ohio law, I became eligible for parole after less than $41 / 2$ years. Accordingly, I appeared before the parole board in 1986. Because I was serving a 180-day term in solitary confinement for having committed the offense of going on a hunger strike to protest the ODRC's refusal to recognize and respect the religious rights of American Indian prisoners, I was brought before the parole board clad in handcuffs and [shackles]. The members of the parole board stated to me at that time that, if I were released on parole, I could practice my traditional religious beliefs, the implication clearly being that, if I were to drop the religious issue and impending lawsuit against the prison officials for religious deprivations, I would be granted a parole. I explained to the parole board that, as a result of my hunger strike, I was denied the right to attend my brother's funeral, a privilege enjoyed by all other prisoners in Ohio; I was sprayed in the face with a fire extinguisher; I was kicked and punched by prison guards while defenselessly handcuffed and shackled; I was incessantly ridiculed by prison staff; and I received extensive sensory deprivation in solitary confinement. I told the parole board that, if I forsook my brothers, they would have to go through what I have gone through merely for asserting the right to pray in the manner that was given to our people by God. I told the parole board that I could not forsake my brothers.

3 When I refused to drop the religious issue, as set forth above, the parole board denied my parole and told me I would become eligible for parole again after five more years. The 'official' reason given me for the denial of parole was that, in the parole board's opinion, I was an alcoholic and drug addict and they wanted me to participate in Alcoholics Anonymous and/or Narcotics Anonymous (AA/NA), and if expected to be released at any time in the future, I would have to participate in these programs. This official reasoning was entirely inappropriate, for nothing in my recorded history was ind icative of my having an alleged drug or alcohol problem, and I stated as much to the parole board.

4 Under Ohio law, when a prisoner is given a 5-year extension by the parole board as I was given in 1986, the prisoner is given a review after $21 / 2$ of the five years. Accordingly, I appeared before the parole board after $21 /$ 2 years (this was in 1988 or 1989). At this time the parole board expressed their dissatisfaction with the fact that I had failed to get involved in the 
AA or NA programs. I stated to them (and this statement is recorded in the files of the parole board because I mailed them a written copy of the statement in advance), that I clearly had no drug or alcohol problem, a fact that was demonstrated by the work I had been doing in the field of Indian Affairs during my incarceration. I stated further to the parole board that, if I had a drug or alcohol problem and if the parole board was sincerely concerned about my need for treatment, then the appropriate treatment for me could not be found in the AA or NA programs, but rather in the traditional American Indian religious traditions of my pcople. I stated further that the philosophies of AA and NA are contrary to my own religious, cultural, social, and political philosophies and beliefs, and that to force me into AA or NA would, therefore, be a violation of my rights as are clearly established under international law and United States law. Every aspect of my statement to the parole board was verified in letters the parole board received from social scientists and legal scholars who are experts on the subject matter.

5 Notwithstanding the documentation and statements presented to the parole board as described above, I was again denied parole and told by the parole board that, if I ever expected to be released from prison, I must participate in AA and/or NA.

6 My statement to the parole board regarding AA and NA and the adverse effects those programs have on American Indians due to conflicting values and beliefs was expanded into a major thesis on the subject matter. This thesis, entitled Rehabilitation: Contrasting Cultural Perspectives and the Imposition of Church and State' was published in the Journal of Prisoners on Prisons, a publication used as a pedagogical tool by professors of criminology and criminal justice in the United States and Canada. The first page of the article, which is attached hereto as Exhibit-A, contains a footnote in which I stated that a 'special thanks goes to each and every member of the Ohio Parole Board whose in humanity inspired this work.' This thesis (and the footnote) was presented at various conferences such as those of the Academy of Criminal Justice Sciences, the American Society of Criminology, and the International Conference on Penal Abolition, among others. The members of the parole board were aware of this article and the high acclaim it was receiving at these conferences and by the professors who were making it required reading for their students majoring in criminal justice. For example, Dr. Robert Caucher, a professor of criminology at the University of Ottawa (Ontario), personally contacted the parole board and made them aware of the article's use at these conferences and universities. Dr. Gaucher will verify this if contacted. See Exhibit-5.

7 The article referred to in paragraph 6 above is only one of a long list of articles I have had published in which I have been exposing human rights violations committed by the Ohio Adult Parole Authority and other of ficials within the ODRC and Ohio government. Another example of my work that the Adult Parole Authority was aware of is an article, The American Indian in the White Man's Prisons: A Story of Genocide,' which was published in the mid-to-late 1980s in Humanity and Society, the official journal of the Association for Humanist Sociology and in The Other Side magazine and in the Journal of Prisoners on Prisons. This particular article, which is attached hereto as Exhibit-B, exposes various 
crimes committed by ODRC officials and their attorneys, such as the Ohio Attorney General and ODRC having knowingly employed a fraudulent Indian chief of a non-existent 'Indian Tribe' to testify - on more than one occasion - as an 'expert' against Indian prisoners who have filed lawsuits against the ODRC for religious freedom deprivations. My having such articles published in various magazines and journals throughout North America caused the Parole Board to hold contempt for me, a contempt expressed through their treatment of me which has been unlike the manner in which they routinely treat prisoners and parolees in the state of Ohio, which I will now attempt to describe.

8 During my incarceration in the ODRC, I watched other prisoners with convictions and sentences similar to mine come and go. If I had been treated by the Adult Parole Authority in a manner consistent with the way in which all other prisoners with my record, my history, my sentence, and my behaviour within the prison system are treated, I would have been granted a parole after serving $41 / 2$ to seven years. To use some cases in point, I am able to identify two prisoners who were convicted and sentenced after me who I knew well. Both of these prisoners were sentenced to at least 7 to 25 years for aggravated robberies, and they were both repeat offenders. The only significant difference between these two prisoners and me was that I maintained a fairly clean conduct record while incarcerated, my greatest offense during incarceration being the hunger strike described above, while both of these prisoners had been found guilty of such serious offenses as stabbing other prisoners with knives - on more than one occasion in one of these prisoners' cases. Both of those prisoners were released on parole several years before I was.

9 Many people-family, friends, social scientists and lawyers, and the like - wrote letters to the parole board expressing their feeling that I was a political prisoner because the parole board's reason for keeping me in prison no longer had anything to do with my original conviction and sentence, but was the result, rather, of my political activities as described above. I believe that it was because of this enormous public pressure that the parole board decided to drop the AA/NA issue and to reduce the five years they had previously given me to four years so that I would be eligible for parole in 1990. Accordingly, I appeared before the parole board in October of 1990 and without any discussion whatsoever, they notified me that they had decided to grant me a parole and I was scheduled for release from prison on December 21, 1990.

10 After the parole board notified me that I was to be released on parole on December 21, 1990, one of their agents approached me and demanded that I sign a contract in which I would relinquish constitutional rights which I had retained, and which all prisoners retain, even while incarcerated in maximum security prison. I complained that this contract was illegal, that to force my signature to be executed on the contract would be a violation of clearly established law, and that the Ohio Adult Parole Authority had no lawful authority to impose this contract on me. I supported my complaint with case law as well as with sections of the United States Code, and I asked the parole board to identify any error in my presentation of the law or any law upon which they relied to impose the terms of this contract on me. I told them that, if the law did, in fact, 
authorize them to impose this contract on me, I would certainly be willing to cooperate.

11 During the process of my complaint, as set forth in paragraph 10 above, I was in a pre-release program at a minimum security prison to which I was transferred when granted parole at the October 1990 meeting with the parole board referred to in paragraph 9.

12. The chairman of the parole board met with me in regard to my complaint described above. He told me a lot of things that I won't repeat here in detail. I will, however, say that he assured me that he was going to do everything in his power to see that I serve each and every day of my 25year sentence in prison. He also stated that he doesn't give a damn about my so-called constitutional rights. At the conclusion of that meeting he handed me a piece of paper which stated in his own handwriting that my parole was being taken away from me because 'this inmate said the conditions [of the parole board's contract] as they stand violate his constitutional rights.' This stated reason for taking my previously granted parole was in direct violation of clearly established law. According to what the parole board had now been stupid enough to put in writing, I was being held in prison for no reason other than asserting my constitutional rights. I was then shipped back to maximum security.

13 I filed a petition for writ of habeas corpus against the parole board in the case of Little Rock Reed v. Arthur Tate, Jr., and Ohio Parole Authority, case number 91-CI-122 (Scioto County Court of Common Pleas), in which I presented evidence [substantiating] the factual allegations I have made in paragraphs 10-2 above. The record in that case will reveal that theOhio Adult Parole Authority admitted that each and every one of my factual allegations set forth in paragraphs 10-12 above are true. In that case, they admitted further that the contract they attempted to force me to sign was illegal and they had no lawful authority to impose such a contract on me. They admitted further that all of my legal arguments were entirely valid and that they had no statutory or case law upon which to rely as a defense to my claims. They argued, however, that because I was originally sentenced to a maximum of 25 years in prison, they should be able to make me serve every day of it in prison without having their motives examined by any court of law. The judge in that case agreed with them: since I was originally sentenced to [an indeterminate sentence of] 25 years, the court held. I have no right to ask any court to examine the parole authority's actions against me until I have actually served 25 years in prison. All of what I am saying here is documented in the court record in the case cited above.

14 So that my appeal in the habeas corpus action described above would become moot, the parole board granted me a parole and I was released in May of 1992. Within a couple of weeks after my release from prison, my parole officer granted me permission to travel to South Dakota, unsupervised, for two weeks, so that I could participate in the Sun Dance, a religious ceremony. Not long after this, my parole officer granted me permission to travel to Utah to speak at the 43rd annual conference of the Governors' Interstate Indian Council, an organization comprised of commissioners of Indian Affairs in the approximately thirty-eight states that have such councils or commissions established for consultation to the 
state governors. My purpose for speaking at the conference was to address religious freedom issues on behalf of American Indian prisoners throug $\mathrm{ft}$ the United States. Attached as Exhibit-C is a letter I received from $W_{1}$ Numkena, host of the conference in Salt Lake, thanking me for the important role I played at the conference. Exhibit-D is a resolution strongly supporting Indian prisoners' rights which was adopted by the Governors' Interstate Indian Council as a direct result of the information I presented at the conference - much of which exposed what participants at the conference perceived as criminal behaviour of the Ohio prison officials and Parole Authority.

15 My parole officer allowed me to speak at other conferences as well, including, for example, a state-wide gathering of Indian organizations at the Ohio University at Columbus in October 1992. The content of my speech was arousing many people's concern about the atrocities being committed against American Indians by the officials within the ODRC. Sce, for example, the affidavit of Lance Kramer, Assistant Provost at the Ohio State University and assistant director of the Ohio Centre for Native American Affairs, attached as Exhibit-E.

16 Within several days after the state-wide meeting referred to in paragraph 15 , my parole officer called me to his office and told me that my public speaking was getting high-ranking ODRC officials upset. He told me that the chief of the Adult Parole Authority contacted him and ordered him to see to it that I stop speaking. He told me that the chief of the Adult Parole Authority told him to order me to cease all correspondence with prison officials in Ohio on behalf of American Indian prisoners or my parole would be revoked. This last order was a direct result of correspondence I had initiated with Ohio prison officials in which I was able to get them to un wittingly admit to their human rights violations against Indian prisoners. A true and accurate copy of such damaging correspondence is reprinted in a chapter of a book soon to be published by Vintage Books, a division of Random House, Inc.. A copy of that chapter is attached hereto as Exhibit-F. ${ }^{4}$ One of the authors of the correspondence I refer to which is contained in Exhibit-F, Marlo Karlen, Administrator of Religious Services for the ODRC, implied in said correspondence that my parole would be revoked if I continued this activity. Lenny Foster, spiritual leader and director of the Corrections Project of the Navajo Nation, also told me that Marlo Karlen told him that he was outraged that I would force prison officials to meet with Indian representatives to discuss ODRC policies, and that I belong in prison for causing these problems and making his job difficult. Foster told me that Karlen stated to him that Karlen intended to contact the ODRC's legal counsel to see what could be done in the way of having my parole revoked. Karlen made these statements to Foster, as Foster will attest if contacted, approximately one day before my parole officer ordered me to stop corresponding with prison officials as set forth above.

17 When my parole officer told me I would no longer be able to travel to speaking engagements (even within the state of Ohio), I was forced to cancel several engagements, including some conferences I had been scheduled to speak at, such as the annual conferences of the Catholic Committce of Appalachia (approximately a 2-hourdrive from my home), the Commission on Religion in Appalachia (approximately a 2-hour 
drive from my home), a Christian conference at the Ohio State University in Columbus (approximately a 2-hour drive from my home), and a Christian conference at a church in Covington, Kentucky (approximately a 5-minute drive from my home). I also had to cancel plans to testify before the United States Senate Select Committee on Indian Affairs concerning the religious rights violations and persecution of American Indian prisoners. My parole officer told me that, if I appeared to speak at any of these conferences, he would be forced to revoke my parole as ordered by the chief of the Adult Parole Authority. He said he was sorry, but that this was being controlled by the highest ranking officials in the Parole Authority and he was only following orders. He also told me that this was the only time in his career as a parole officer that he had ever been personally contacted by the chief of the Adult Parole Authority and given such orders regarding any parolee.

18 It is the standard policy and practice of the Ohio Adult Parole Authority that if a parolee wishes to travel for any purpose, the parole officer is the person who decides whether or not the parolee may do so. Such decisions are never made by officials at the central office in Columbus except in my case. My parole officer admitted that he had absolutely no control over my travel requests and that these decisions in my particular case were being made by his superiors. In addition to admitting this to me, he admitted it to William Weathers, a reporter for the Kentucky Post. See Exhibit-G, an article by William Weathers in which he reports such a statement by the parole officer.

19 When an Ohio parolee's job requires that he travel (for example, a parolee who drives a truck for a living), the parole officers as a general practice allow the parolee to travel. The travel requests I made which were denied were job-related, as I was to speak at conferences in my capacity as the director of the Native American Prisoners' Rehabilitation Research Project (NAPRRP). In denying my job-related travel requests and in having such decisions made at central office in Columbus rather than by the parole officer, and clearly so as to suppress my speech, the Ohio Adult Parole Authority violated my rights to free speech and to petition the government for red ress of grievances and to equal protection of the laws, as well as to due process.

20 While on parole, I was doing everything in my power to comply with the conditions of my parole and I was working hard full-time as well as attending college full-time. My academic goals were clearly set and I was in the process of completing my bachelor's degree with a major in Criminal Justice and Indian Affairs, with plans to begin working on my doctoral dissertation (a text book entitled An Introduction to Indian Studies). The plans were certainly realistic, as I have written various papers that are used as required reading in college courses in the United States and Canada, and professors of Indian Studies and of Criminal Justice have already informed me that they plan to use a book I have just completed as a text in courses they teach. See, for example, letters of confirmation from Cindy Kasee, an Indian Studies professor in Florida, and Hal Pepinsky, a criminal justice professor in Indiana, attached hereto as Exhibits-H and I, respectively. See also the affidavit of Bill Williams, my academic advisor at the Union Institute, attesting to the hard work I 
was doing as a student at the Union Institute while on parole. (ExhibitJ.)

21 While working full-time and attending college full-time, I had been fortunate enough to meet some sincere people who believed in what I was doing and who wanted to support the objectives of the NAPRRP. One such person was Dinah Devoto, a city council member in Villa Hills, Kentucky, the same town that the offices of the NAPRRP are located in. Ms. Devoto's husband, however, did not see eye to eye with Ms. Devoto, and he expressed a concern that her affiliation with me and the NAPRRP (an ex-convict and an organization that supports criminals) would damage the reputation of [him] and his family in the minds of the community members of Villa Hills. He demanded that she stop affiliating with me and the NAPRRP and she refused to do so. Accordingly, he threatened my life, unprovoked, over the telephone. He contacted me and told me to stay away from his wife, children, and house, and he cussed at me. I hung up on him but was very upset by his call and I immediately called him back and said that perhaps we could meet somewhere and resolve the matter right now. At that time, heyelled, "I'1l blow your fuckin' head off you sunuvabitch!" I responded that, during my thirteen years of imprisonment, I have learned to deal with people like him (meaning people who make threats from afar), and I told him that if he came near me with a gun I would take it away from him and stick it up his ass. I then hung up on him and that was the end of it as far as I was concerned.

22 A week after I was threatened over the telephone by Steven Devoto as described above, I was served a summons to appear in court to answer charges he had placed against me for allegedly threatening his life. A copy of his sworn statement is attached hereto as Exhibit- $K .^{5}$ If his statement is to be taken at face value, I am obviously an idiot who threatens to kill people for no reason at all, without any apparent motive. If his statement is to be believed, he never implied that he would blow my head off. However, his 6-year-old daughter, Grace, stated later that she personally heard him threaten to blow my head off. She made the statement in the presence of both her mother and her father. See the affidavit of Dinah Devoto attached hereto as Exhibit-L.

23 After I was served a summons as set forth above, I was told by Claudia Aylor that Steve Devoto stated to her a couple of weeks previously that he would do something to me. He clearly threatened me in conversation with Ms. Aylor, but Ms. Aylor never told me about it previously because she was afraid I would confront Devoto about it and possibly get into trouble. See Ms. Aylor's affidavit attached hereto as Exhibit-M.

24 After I was served the summons as set forth above, I was told by Dinah Devoto that Steve Devoto had threatened me on numerous occasions in conversations with her, but she withheld this information from me for the same reason Claudia Aylor did. See the affidavits of Dinah Devoto attached hereto, Exhibits- $L$ and $N$.

25 I was served the summons referred to above in the evening at the Villa Hills office of the NAPRRP. The police arrived to serve me the summons at approximately 8:00 PM. Actually, I know that Claudia's clocks said 7:55 PM when the police arrived because we both checked the clocks at 
that time. The police who served the summons [who are friends of Steve Devoto] claim that they arrived at 8:10 PM. I won't attempt to argue about the variance because I was at the Villa Hills add ress until about 8:40 that night anyway because my brother, Matthew Scull, didn't arrive to pick me up until 8:40 PM. He would generally pick me up at 8:00 PM and we would catch the last ferry across the river (a couple minutes past eight is when the last ferry runs). He has been late to pick me up on several occasions, and the night I was served the summons was one of those occasions. See the affidavit of Matthew Scull attached hereto as ExhibitO. The reason Matt would usually pick me up at 8:00 PM is because I had written permission from my parole officer to be in Villa Hills, Kentucky at that address from 8:00 AM to 8:00 PM. seven days a week to work for the NAPRRP. And the reason I mention all of this is that my parole officer has stated that the Adult Parole Authority feels that because I was at the Villa Hills office after 8:00 PM, I have violated the conditions of my parole and these are grounds to return me to prison. I'll bet I'm the first parolee in the United States ever to have parole revocation proceedings initiated against me for the crime of working at the office ten minutes over-time.

26 At 9:00 AM on the morning after, I was served the summons as described above, I was on the telephone to contact my parole officer to inform him about the charges Steve Devoto placed against me. I stated to the parole officer all of the above facts relating to the threat and to the charges except at that time I was unaware that Devoto's daughter, Grace, personally heard him threaten to blow my head off. For this reason, that is the only information I didn't give to the parole officer. I also informed him that Steve Devoto had stated to his wife that he was going to drop the charges, and that they were not accurate. I also told the parole officer that I had in my hand the sworn affidavit of Dinah Devoto, swearing that Steve set me up and that the charges against me were false. The parole officer told me that I must turn myself in to his office on the following Monday morning at 9:00 AM so that he could take me into custody and place me in jail and initiate parole revocation proceedings. I couldn't believe what he was telling me, and I asked if he would arrest me even if Steve Devoto and Dinah Devoto came in with me on Monday morning to verify that I had never made a threat against Devoto. The parole officer told me it didn't matter. He said he was going to arrest me anyway because that is the policy regardless of any evidence of my innocence. Matthew Scull was sitting at the kitchen table with meduring my phonecall to the parole officer and he heard my end of the conversation and can attest to the same. Sce the affidavit of Matthew Scull attached hereto as Exhibit-O.

27 At approximately 7:00 PM on the day after I was served the summons as set forth above, Dinah Devoto called my parole officer to verify that the charges against me were false and that her husband threatened me - I didn't threaten him. At this time the parole officer informed Dinah Devoto that the parole board holds contempt for me because of my political activities, and they would now have an excuse - regardless of my innocence - to revoke my parole and force me to serve the remaining years of my 25-year sentence in prison. See the affidavit of Dinah Devoto attached hereto as Exhibit-L.

28 If I had showed up at my parole officer's office on the following Monday morning as he ordered me to do, I would have been arrested and placed 
in jail. The parole officer stated as much to me as set forth above, and to Dinah Devoto (see Exhibit-L), and to my grandmother, Gladys McAllister (see Exhibit-P).

29 Prior to the Monday morning that I was to turn myself in, my parole officer told Dr. Hal Pepinsky over the telephone that when I report to his office on that Monday, he planned to pick up the telephone and contact his superiors in Columbus, Ohio, to receive instructions as to what action to take against me. See the affidavit of Harold (Hal) Pepinski, attached hereto as Exhibit-Q.

30 The day after Dinah Devoto and I contacted the parole officer to inform him of Steve Devoto's false charges, Devoto's attorney contacted my parole officer's superiors in Columbus. As a result of that contact, the Adult Parole Authority issued a warrant for my arrest. This action against me by the officials in Columbus was contrary to the routine procedures of the Adult Parole Authority. The arrest orders, and the decision to issue such orders, are as a matter of standard procedure (as well as statutory law - see section 2967.15 of the Ohio Revised Code) carried out by the parole officers, not the officials in Columbus. ${ }^{6}$

31 Since my parole officer planned to contact the officials in Columbus (the same officials who issued the arrest order) for instructions as to what actions to take against me as set forth in paragraph 29 above, my right to due process was violated from the beginning. No one directly involved in my arrest is allowed to participate even indirectly in the decisionmaking process that was to occur when the parole officer sought instructions from his superiors in Columbus. See Morrisey v. Brewer, $92 \mathrm{~S}$. Ct. 2593 (1972). My due process rights as set forth by the Supreme Court in Morrisey v. Brewer were also violated in that the decision-making process is to be performed by a 'neutral and detached' decision-maker. Because of the contempt for me which is harboured by the Adult Parole Authority in Columbus, and because of the long-standing pattern of abuse toward me which has resulted from that contempt, it is my contention that no parole revocation procedural hearings conducted by the Adult Parole Authority or anyone appointed by the Adult Parole Authority [in my case] can possibly be conducted in a 'neutral and detached' fashion.

32 I have been told by several people who have been in contact with my parole officer, including Kentucky Post reporter Bill Weathers, that two additional reasons exist as ground to revoke my parole [according to the parole officer]:

1) I had moved to the Villa Hills address and was living there without having first notified my parole officer or sought his permission to change my residence; and

2) I failed to report to traffic court in Cincinnati to answer for a ticket I received as a result of a car accident.

33 There is absolutely no evidence that I was living at the Villa Hills address. I was there working from 8:00 AM to 8:00 PM seven days a week, and I had permission to do so. I was living at my mother's address in Cincinnati. See the affidavits of Nancy Scull, Matthew Scull, Gladys McAllister, and Claudia Aylor, attached hereto, respectively, as Exhibits $\mathrm{R}, \mathrm{O}, \mathrm{P}$, and $\mathrm{M}$. 
34 The reason I didn't pay the fine for the ticket I received (for 'failure to control') as a result of a car accident referred to above is that I was going to be found not guilty of the violation. The cause of the accident was the slush on the road. I was driving $10 \mathrm{mph}$ in a $35 \mathrm{mph}$ speed zone. I violated no law, and the woman I bumped into as well as the officer who issued the ticket, were prepared to come to court to testify on my behalf. The reason I failed to appear at that traffic court is that the court date was subsequent to the date I failed to turn myself in to the paroleofficer so that I would be jailed as a result of Steve Devoto's false charges against me. Ultimately, my grandmother paid the traffic fine and the case in traffic court was closed.

35 Thereare many documents contained in the files of theOhio Adult Parole Authority which substantiate my claims [against] the Adult Parole Authority. For example, there are copies of correspondence between me and members of the Adult Parole Board, the chief of the Adult Parole Authority, and my parole officer. If the parole officials deny that such documents exist, I will locate the copies I have stored away ... .

36 I declare that the foregoing statement of facts is true and accurate to the best of my knowledge and belief, and I hereby affix my signature to it under penalty of perjury.

Much has happened since the above affidavit was executed on April 28, 1993. On June 29,1993, Little Rock was tried en absentia on the Kentucky charge. The trial only lasted an hour, in which Steven Devoto testified that Little Rock, without provocation, threatened Devoto's life. Devoto's testimony was the only evidence against Little Rock. Testimony for the defense included the following:

- Dinah Devoto, the wife of Steven Devoto, testified that on numerous occasions her husband had told her that he was going to 'get rid' of Little Rock if she continued to support Little Rock's organization, the Native American Prisoners' Rehabilitation Research Project. Mrs. Devoto also testified that on the day her husband threatened to blow Little Rock's head off, he (Devoto) bragged to her about his having threatened to blow Little Rock's head off.

- Grace Devoto, the6-year-old daughter of Steven Devoto, testified (through stipulation) that she heard her father threaten to blow Little Rock's head off.

- Claudia Aylor, assistant director of the Native American Prisoners' Rehabilitation Research Project, testified that prior to the telephone conversation in which Little Rock is alleged to have threatened Devoto, Steven Devoto told Aylor that he would do anything he could to have Little Rock placed back in prison and that he would call on favours owed him by Villa Hills police officers, if necessary, to accomplish it.

On cross-examination, Steven Devoto again swore that he had never threatened Little Rock and that neither his wife, nor his daughter, nor Claudia Aylor were telling the truth. Accordingly, the judge found Little Rock guilty as charged. 
Little Rock, upon hearing of the verdict, immediately filed a pro se motion for a new trial based on the ineffective assistance of trial counsel. His motion was based on the fact that trial counsel, without consulting with Little Rock (which he is by law required to do), decided not to elicit testimony from Claudia Aylor regarding her having witnessed Little Rock's end of the telephone conversation. She is the only first-hand witness, aside from Little Rock, to Little Rock's end of the phone conversation. Without her testimony to this, there was no evidence with which to refute Steve Devoto's claim that Little Rock threatened his life. Additionally, Little Rock's pleadings in support of a new trial indicated that his trial attorney had failed to elicit further testimony and evidence (of which he was aware prior to the trial) that would have served to vindicate Little Rock, including:

- Dinah Devoto made trial counsel aware (through affidavit) that she contacted the Acting Regional Administrator of the Ohio Adult Parole Authority who verified that Steve Devoto, in an initial state of remorse for having pressed false charges against Little Rock, called the Parole Authority to inform them that he was going to drop the false charges, and asked that they take no action against Little Rock.

- Dinah Devoto made trial counsel aware (through affidavit) that when Steve Devoto learned that Little Rock had filed a counter claim against Devoto for threatening Little Rock's life, Steve Devoto retained a lawyer who persuaded him that the best legal strategy would be to maintain the charge against Little Rock notwithstanding Little Rock's innocence, since Little Rock was an ex-convict on parole.

- Dinah Devoto made trial counsel aware (through affidavit), as did Little Rock through telephone conversation, that Steve Devoto and his lawyer made Little Rock believe that Little Rock was to meet with Devoto and his lawyer for the purpose of signing an agreement whereby the charges would be dropped, while in reality, Devoto's lawyer was on the telephone getting Ohio Adult Parole Authority officials to issue a warrant for Little Rock's arrest. The testimony of Dr. Hal Pepinsky would have corroborated this as well, a fact of which trial counsel was aware prior to the trial.

- Trial counsel had in his possession affidavits and other extensive documentation demonstrating that Little Rock had over the years become a nationally recognized advocate for peace, including evidence that he was personally responsible for keeping prisoners from rioting at the prison in Lucasville, Ohio, yet counsel made no effort to introduce any evidence or character witnesses that would have indicated that the threat he was alleged to make against Devoto is directly contrary to his nature.

In addition to bringing this evidence to the court's attention in his pro se pleadings, Little Rock pointed out that the charge itself was inapplicable to the case according to Kentucky law, something his trial counsel failed to point out to the court, which indicates that trial counsel did not do any legal research in Little Rock's case. From Little Rock's pro se motion:

The evidence in this case ... indicates that Steve Devoto did in fact threaten to blow Defendant's head off, which was a threat against Defendant's life. 
[The] evidence indicates further that in response to Devoto's threat against Defendant's life, Defendant reacted by stating that IF Devoto came after Defendant armed with intent to kill Defendant as threatened, and IF Devoto did not succeed in killing Defendant, Defendant would A) take the gun away from his attacker and 'stick it up [his attacker's] ass,' or B) kill his attacker.?

Assuming arguendo, that the latter response is the response Defendant made to Devoto's threat against his life, this Court must nevertheless dismiss this case. In Thomas v. Commonwealth of Kentucky, 574 S. W. 2d 903, the [Kentucky Court of Appeals], in discussing the legislative intent of the statute Defendant is charged with, explained that the statute [Kentucky Revised Statute section $508.080(1)(\mathrm{A}))$ :

is taken from section 211.3 of the Model Penal Code (10 ULA), p. 539 entitled 'Terroristic Threats' ... . The drafters' comments following this section of the Model Penal Code ... explain the application of this section: ... 'In drafting legislation penalizing threats, we would not wish to authorize ... sanctions against the kind of verbal threat which expresses transitory anger rather than settled purpose to carry out the threat or to terrorize the other person ... .' (574.2 S. W. 2d at 907.)

It is thus clear that the Kentucky Supreme Court and the Kentucky legislature did not intend for this statute to apply to cases such as the instant one, where the Defendant's alleged threat against Devoto was merely an expression of transitory anger and fear after having his own life threatened rather than a settled purpose to carry out a threat or to terrorize the other person.

Little Rock's motion for a new trial was denied. The conviction, therefore, constitutes an incontestable technical parole violation authorizing the Ohio APA to place Little Rock back in prison for fifteen years, if and when apprehended. The effect of the conviction in Little Rock's case, therefore, is equivalent to more than two consecutive life sentences under Kentucky law, as parole eligibility on a life sentence in Kentucky arrives after seven years. Little Rock is appealing the conviction and has stated that, where tax-payers are concerned, this case will very likely be the most expensive misdemeanour case ever tried or litigated in United States history.

Since the day Little Rock went underground, the APA and other prison officials who want him in prison have discovered even greater cause for wanting his voice silenced. As stated in a May 25, 1993, affidavit signed by Dr. Harold Pepinsky, a board member of the American Society of Criminology who has been monitoring some of the conditions at Ohio's maximum security prison in Lucasville for several years now:

The prison wing [Little Rock] would have undoubtedly been sent back to in Lucasville had he reported to his parole officer this past March 22 shortly thereafter broke out in a riot. There he would have been a likely choice of rioting prisoners to be their spokesperson. Had he survived the riot, he would now be a prime candidate for murder prosecution simply by having been in the prison at the wrong time. I believe he might well have died instead. Mr. Reed's fellow writ-writer and defender of American Indian 
Journal of Prisoners on Prisons, Vol. 5, No. 1, 1993.

religious freedom, Dennis Weaver, was brought out of the riot area and later found dead in his cell long before the riot ended, with signs of having been beaten.

During the Lucasville riot, prison warden, Arthur Tate, Jr., and the other prison administrators refused to allow the media to interview the prisoners, even though the prisoners stated that they would kill their hostages if they could not speak with the media. When Little Rock learned of this, he travelled to Ohio and spoke with the media on behalf of the prisoners whose voices were being silenced. He was interviewed by the Columbus, Ohio, $A B C$ television news affiliate which was aired throughout the United States. The Plain Dealer, Ohio's largest newspaper, ran a story in which they exposed some of the facts documented in a lawsuit filed by Little Rock on behalf of Lucasville prisoners which indicated that warden Arthur Tate basically did everything in his power to instigate the riot that occurred. The record in the case further revealed that Tate was warned that the riot was impending, yet he stated to the media during the riot that the administration had no prior warning that a riot was imminent. Tate also told the media that the rioting prisoners' claims of religious freedom deprivation were not true. The untruthfulness of Tate's media statement to that effect was revealed in Exhibit-F of Little Rock's petition to the Governor, where Tate in his own correspondence (reproduced in that Exhibit) made it quite clear that no Indian spiritual leader will ever enter the walls of his prison.

Throughout all of this, Little Rock has been busy as legal consultant and spokesman for the Aboriginal Ute Nation, a group of American Indians terminated by an Act of Congress in 1954 who had asked Little Rock to assist them in their struggle. The Ute people were one of more than a hundred Indian tribes that were terminated in the 1950s and 1960s, yet while the other tribes were entirely terminated, Congress only terminated about one-third of the Uintah, based on racial blood quantum, the result being to divide and destroy not only the tribe but also families. ${ }^{8}$ The effect of termination of the Utes was to dispossess them of billions of dollars worth of land and resources through fraud and deceit; to eliminate their right of self-determination and selfgovernment, so they would become subject to state laws and taxes; and to eliminate their identity as Indian people, so that as individuals they may receive no protection of their rights as Indians under US laws. For example, they may not invoke the Indian Child Welfare Act to enjoin the Mormon State of Utah from ripping their children away and placing them in white Christian (Mormon) homes, which, according to Mormon doctrine, is more or less a religious duty.

Because of his status as a political fugitive - a status which has been discovered by some of the Aboriginal Uintah Nation's foes - Little Rock was recently forced to leave the reservation and go back into hiding. Meanwhile, I am continuing, by myself, the extensive factual and legal 
investigation we started together and were hoping to finish together an investigation which, even though not complete, has exposed the crime of genocide that has been and continues to be perpetrated against the aboriginal people of the Uintah and Ouray Indian Reservation.

\title{
AFTERWORD
}

\author{
After writing this chapter, I showed it to Little Rock. This was his \\ response.
}

The Adult Parole Authority probably thought that, when I was released from prison, the fire in my spirit would die and I'd be quiet, content with my new freedom. But freedom is a relative term, and so long as one human being is oppressed or unjustly imprisoned, no human being is free. So long as my heart beats, I will ask questions, I will write, and I will speak the truth about government officials' atrocities against humanity, and now I think the Adult Parole Authority realizes it. With that realization comes the common sense conclusion that the only way to silence my voice is to make my heart stop beating. Whether or not the Adult Parole Authority has that much common sense, I do not know. But I'm certainly not taking any chances...

\section{NOTES}

1 A California human rights attorney who has been actively involved in American Indian prisoners' rights issues, Deborah Garlin recently moved to the Uintah and Ouray Indian Reservation in Utah to assume the position of probono legal counsel for the Aboriginal Uintah Nation.

2 The petitioners were attorney Ed Kagin of Covington, Kentucky; Dr. William Williams of the Union Institute in Cincinnati, Ohio; Dr. Lance Kramer, assistant provost at the Ohio State University at the time of the petitions' filing and now vice president of the Ohio Centre for Native American Affairs; and Dr. Harold Pepinsky, a retired attorney currently teaching at Indiana University and serving as chairman of the Division of Critical Criminology, American Society of Criminology.

3 Due to space limitations, the nineteen exhibits attached to Little Rock's affidavit, and which are referred to throughout his affidavit, are not included here. However, the petition to the governor with all the attached exhibits, as well as the governor's and the APA's responses, are available from the Native American Prisoners' Rehabilitation Research Project, 2848 Paddock Lane, Villa Hills, KY 41017, for \$10.50, which will cover the costs of copying and postage. Any other contributions with which to carry on the campaign to free Little Rock would be appreciated as well.

4 At the time this affidavit was drafted, this book was under an optional contract with Vintage, but due to the need to get this book out to promote legislation that will protect the rights of Indian prisoners, Little Rock terminated the contract with Vintage. The American Indian in the White Man's Prison: A story of Genocide was published in November, 1993 by Uncompromising Books, P.O. Box 1760, TAOS, NM 87571.

5 According to Devoto's sworn statement, Devoto politely asked Little Rock to leave Devoto's children alone (Dinah Devoto would often bring her children to theNAPRRP office with her and Little Rock would play with them and tell them stories, give them ice cream and the like). In response to Steve Devoto's 'polite' request, Devoto claims that Little Rock told Devoto that 'because he [Little Rock] had been in prison for 13 years, he knew "how to deal with people like you - I'll kill you, motherfucker."'

6 In an April 28, 1993, affidavit of Dr. Harold Pepinsky, he stated:

I confirmed by telephone call to [Little Rock's] mother that local police had searched her home Saturday, March 20, for [Little Rock] under the authority of an arrest warrant which under Ohio law could only lawfully have been signed by the parole 
officer. Nonetheless, the parole officer on Sunday, March 21, denied any knowledge of an existing warrant for [Little Rock's] arrest, and tried to reassure me that a decision whether to arrest Mr. Reed would not be made until he checked with Columbus the following morning.

7 As a matter of fact, if Devoto had attempted to carry out his threat against Little Rock, and if Little Rock had killed Devoto in response to such an attempt, Little Rock's killing Devoto would have been permissible under Kentucky's self-defense law. Accordingly, even if Little Rock told Devoto that he would kill Devoto if he attempted to carry out his threat against Little Rock, Little Rock's counter-threat would have been permissible under Kentucky law. Had Little Rock's trial attorney taken the time to research the law concerning the matter, he would have known this and brought it to the court's attention, which he did not do.

8 Approximately $89 \%$ of the terminated Utes were Uintah, one of the three bands of the Ute tribe. The Uintah were the original land holders, to whom the reservation belonged, while the other two bands were relocated by military force to the Uintah reservation more than a decade after its establishment in 1861.

\section{REFERENCES}

Morgan, Lisa, and Little Rock Reed. 1993. 'Editor's Introduction.' Journal of Prisoners on Prisons, 4 (2): 1-3

Reed, Little Rock. 1989. 'The American Indian in the White Man's Prison: A Story of Genocide.' Journal of Prisoners on Prisons, 2 (1): 41-56 [also appears in Humanity and Society, 1987; The Other Side, 1988]

-1990. 'Rehabilitation: Contrasting Cultural Perspectives and the Imposition of Church and State.' Journal of Prisoners on Prisons, 2 (2): 3-28

- 1993a. 'America: With Liberty and Justice for All and Other Myths and Fairy Tales.' Journal of Prisoners on Prisons, 4 (2): 5-16

- 1993b. 'No Neutral Ground.' Journal of Prisoners on Prisons, 4 (2): 119 